\title{
Wykorzystywanie koncepcii mądrości tłumu w działalności bibliotek
}

STRESzCzEnIE: Wydzielenie z organizacji pewnego obszaru działalności i oddanie go w ręce tłumu - zorganizowanej społeczności internetowej - w formie otwartego zaproszenia określa się mianem crowdsourcingu. Obecnie crowdsourcing jako metoda pozyskiwania innowacji jest wdrażany przede wszystkim w przedsiębiorstwach i organizacjach pozarządowych. Ponieważ wprowadzanie rozwiązań na nim opartych jest proste, coraz częściej towarzyszy także działaniom obywatelskim i społecznym, w tym przedsięwzięciom inicjowanym przez archiwa, muzea i biblioteki. Artykuł przybliża istotę crowdsourcingu, jego rodzaje i przykłady wykorzystania jego mechanizmów w działalności bibliotek.

SŁowA KLUCzowE: biblioteki, crowdsourcing, inteligencja zbiorowa, mądrość tłumu

\section{Crowdsourcing, tị. czerpanie z mądrości łłumu}

W raz z rozwojem koncepcji Web 2.0, promującej idee otwartości, dzielenia się wiedzą i globalnego współdziałania, zdecydowanej zmianie uległo postrzeganie użytkownika sieci. Internautę pojmowanego w dobie Internetu pierwszej generacji wyłącznie jako odbiorcę tre-

* Niniejszy tekst jest zmodyfikowaną wersją anglojęzycznego artykułu autorki pt. Crowdsourcing in Libraries, skierowanego do druku na łamach pracy zbiorowej pod roboczym tytułem „Wokół książki, biblioteki, informacji: stan obecny - wyzwania - perspektywy", przygotowywanej w Instytucie Bibliotekoznawstwa i Informacji Naukowej UMCS w Lublinie, której publikację zaplanowano na rok 2013. 
ści i konsumenta, zaczęto traktować jako partnera, powierzając mu rolę kreatora treści serwisów internetowych oraz współtwórcy i ambasadora produktów ulubionej marki (ang. prosument). Konieczność poprawy konkurencyjności zmusiła wiele firm i przedsiębiorstw do sięgania nie tylko do potencjału intelektualnego pojedynczych osób, ale także całych społeczności internetowych. Ponieważ rozwiązania wypracowywane przez rzesze internautów zaczęły przynosić lepsze rezultaty niż powierzanie zadań firmom outsourcingowym czy ich realizacja własnymi środkami ${ }^{1}$, korzystanie z mądrości tłumu stało się coraz chętniej wdrażaną w sektorze gospodarczym metodą pozyskiwania innowacji.

W 2006 r. na określenie różnych form współpracy z użytkownikami sieci pojawił się termin crowdsourcing (crowd - z ang. „tłum”; sourcing z ang. „czerpanie ze źródeł”). Po raz pierwszy użył go Jeff Howe w artykule The Rise of Crowdsourcing. Autor określił nim zjawisko wykorzystywania zaangażowania społeczności, jej talentu, wiedzy i umiejętności do rozwiązywania problemów oraz optymalizacji kosztów działalności przedsiębiorstw². Opierając się na licznych przykładach z sektora gospodarczego, Howe wykazał, że zjawisko czerpania z mądrości tłumu polega na powierzaniu jakiegoś zadania nie wewnętrznemu zespołowi lub pracownikowi danej firmy, lecz niezdefiniowanej grupie ludzi w formie otwartego zaproszenia. Coraz częściej grupę tę stanowi społeczność internetowa, składająca się z amatorów i pasjonatów, wyposażonych w odpowiednie narzędzia komunikacji i wymiany poglądów, która generuje pewną liczbę rozwiązań, dokonuje ich weryfikacji i wybiera najlepsze z nich. Następnie firma zlecająca zadanie nagradza najlepsze rezultaty (finansowo bądź rzeczowo), wdraża je i na tej podstawie generuje zysk ${ }^{3}$.

Howe wskazał także na potencjalne możliwości wykorzystania crowdsourcingu i stworzył pierwszą nieformalną typologię crowdsourcingu, do którego przejawów zaliczył:

- inteligencję zbiorową (ang. collective intelligence, wisdom of the crowd) - rozwiązywanie problemów przez tłum, np. 99designs.com, YourEncore.com, NineSigma.com;

- tworzenie wartości przez tłum (ang. crowdcreation, user-generated

1 T. Doligalski, Współtworzenie wartości z klientami zorientowane na innych klientów, „E-mentor” 2011, nr 1 (38), s. 72-73.

2 J. Howe, The Rise of Crowdsourcing, „Wired” [on-line] 2006, vol. 15, no. 6 [dostęp 30 listopada 2012]. Dostępny w World Wide Web: http://www.wired.com/wired/archive/14.06/crowds.html.

3 Tamże. 
content) - wykorzystywanie potencjału twórczego użytkowników do kreowania nowych produktów, usług i treści, np. iStockphoto. com, Youtube, Wikipedia;

- zlecanie internautom wyboru najlepszych rozwiązań, gromadzenie opinii i sądów na dany temat (ang. crowdvoting), np. Threadless. com, Digg.com, Coolsw.intel.com;

- społecznościowe pozyskiwanie funduszy (ang. crowdfunding), np. KickStarter.com, MyFootballClub.co.uk, Sellaband.com;

- mikropracę (ang. microwork) - wykonywanie za określoną kwotę wynagrodzenia drobnych zadań służących realizacji większych projektów, np. clickworker.com, Taskcn.com, Amazon Mechanical Turk ${ }^{4}$.

$\mathrm{Na}$ podstawie koncepcji Howe'a rozwinęło się wiele różnych podejść do crowdsourcingu. Część autorów przywoływała określone przykłady zastosowania jego mechanizmów, traktując je jako paradygmatyczne, inni natomiast klasyfikowali te same partycypacyjne przedsięwzięcia w zupełnie inny sposób (np. „Wikipedia” była uznawana przez część badaczy za klasyczny przykład crowdsourcingu, przez innych - wręcz przeciwnie) ${ }^{5}$. Wśród kryteriów taksonomicznych uwzględnianych przez badaczy w budowie różnych typologii znalazły się m.in. rodzaj społeczności biorącej w nim udział ${ }^{6}$, charakter współpracy i sposób ewaluacji wyników $^{7}$, wymagania stawiane tego typu przedsięwzięciom ${ }^{8}$, typy wyodrębnianych procesów i możliwości platform systemowych ${ }^{9}$ czy wreszcie punkt widzenia rozpatrywanych problemó $w^{10}$. Specyfika uruchamianych

${ }^{4}$ Tamże; J. Howe, Crowdsourcing. Why the Power of the Crowd is Driving the Future of Business [on-line]. The International Achievement Institute [dostęp 30 listopada 2012]. Dostępny w World Wide Web: http://www.bizbriefings.com/Samples/IntInst--Crowdsourcing.PDF.

${ }^{5}$ Por. E. Estellés-Arolas, F. González-Ladrón-de-Guevara, Towards an integrated crowdsourcing definition, „Journal of Information Science” 2012, no. 20 (10), s. 1-14.

${ }^{6}$ M. Vukovic, C. Bartolini, Towards a Research Agenda for Enterprise crowdsourcing, [w:] Leveraging Applications of Formal Methods, Verification, and Validation, ed. by T. Margaria, B. Steffen, Berlin-Heidelberg 2010, s. 425-434 (Lecture Notes in Computer Science; 6415).

7 A. Doan, R. Ramakrishnan, A. Y. Halevy, Crowdsourcing systems on the World-Wide Web, „Communications of the ACM” 2011, vol. 54, no. 4, s. 86-96.

${ }^{8}$ M. Vukovic, Crowdsourcing for enterprises, [w:] Services 2009: 2009 IEEE Congress on Services: Los Angeles, CA, 6-10 July 2009: proceedings, Part 1, ed. L.-J. Zhang, Piscataway, cop. 2009, s. 686-692.

9 D. Geiger, S. Seedorf, M. Schader, Managing the Crowd: Towards a Taxonomy of Crowdsourcing Processes, [w:] Proceedings of the Seventeenth Americas Conference on Information Systems, Detroit, Michigan, August 4th-7th 2011, Detroit-Michigan 2011, s. 1-11.

10 D. C. Brabham, Crowdsourcing: A Model for Leveraging Online Communities. W: Da- 
projektów sieciowych, angażujących użytkowników sieci w coraz to nowszych obszarach, spowodowała, że katalog rodzajów crowdsourcingu został rozszerzony o:

- nakłanianie do udziału w konkursach (ang. inducement prize contests) - ogłaszanie w sieci konkursów bądź zapraszanie do zgłaszania pomysłów za pośrednictwem platform internetowych, za które ich twórcy są nagradzani rzeczowo lub finansowo, np. Local Motors.com, IdeaConnection.com, IBM Jam Events;

- nabywanie dóbr grupowo w celu uzyskania lepszej oferty (ang. crowdpurchasing), np. Groundswell.pl;

- utajony crowdsourcing (ang. implicit crowdsourcing) - wykorzystywanie działań użytkowników do innych (dodatkowych) celów niż realizacja aktualnie wykonywanych zadan ${ }^{11}$.

Mimo że bezpośrednią przyczyną coraz częstszego wdrażania crowdsourcingu były zmiany, jakie zaszły i nadal zachodzą w Internecie zwłaszcza rozwój koncepcji Web 2.0 i rozkwit ruchu otwartej wynalazczości w dziedzinie oprogramowania ${ }^{12}$ - zjawiska crowdsourcingu nie należy utożsamiać z każdą, istniejącą w sieci społecznością. Nie należy go także postrzegać jako synonimu rozwiązań Open Source. W odróżnieniu od grup zorganizowanych wokół serwisów społecznościowych, których członkowie - z indywidualnych pobudek i w dużej mierze dla własnych celów - komunikują się ze sobą, wyrażają swoje poglądy na temat zawartości zasobów informacyjnych lub opatrują te już istniejące stosowanymi słowami kluczowymi (ang. tag), crowdsourcing zakłada współdziałanie kolektywne na rzecz wspólnego (z reguły większego i ważniejszego) celu i wymaga większego zaangażowania, innego poziomu wysiłku, czasu i wkładu intelektualnego ${ }^{13}$. W przeciwieństwie do ruchu Open Source, który odnosi się do oprogramowania i rozwija się spontanicznie, z reguły bez nadrzędnej kontroli organizacyjnej (wypracowane rozwiązania,

ren C. Brahbam Ph. D. [Weblog] [on-line] 18.03.2011 [dostęp 30 listopada 2012]. Dostępny w World Wide Web: http://dbrabham.files.wordpress.com/2011/03/brabham_handbook_crowdsourcing.pdf.

${ }^{11}$ Crowdsourcing. W: Wikipedia, the free encyclopedia [on-line] [dostęp 30 listopada 2012]. Dostępny w World Wide Web: http://en.wikipedia.org/wiki/Crowdsourcing.

12 Ł. Gajewski, Wykorzystanie koncepcji mądrości tłumu do przyspieszenia tempa rozwoju technologicznego, „E-mentor” 2010, nr 5 (37), s. 61.

${ }_{13}$ R. Holley, Crowdsourcing: How and Why Should Libraries Do It?, „D-Lib Magazine” [on-line] 2010, vol. 16, no. $3 / 4$ [dostęp 30 listopada 2012]. Dostępny w World Wide Web: http://www.dlib.org/dlib/march10/holley/03holley.print.html. 
choć służą dobru całej społeczności, przynoszą prestiż przede wszystkim poszczególnym twórcom programów), crowdsourcing znajduje zastosowanie w sferach innych niż tworzenie oprogramowania. To raczej pewna koncepcja zarządzania innowacjami, ukierunkowana na działalność danej organizacji i przez nią nadzorowana ${ }^{14}$.

\section{Zastosowanie crowdsourcingu}

Crowdsourcing jest na tyle elastycznym zjawiskiem, że może być wykorzystywany w różnych sferach działalności, zarówno w inicjatywach komercyjnych, jak i akcjach społecznych. Potwierdzeniem tej tezy jest długa lista realizowanych współcześnie na świecie projektów crowdsourcingowych, uzupełniana na bieżąco na łamach angielskiej „Wikipedii” ${ }^{15}$. Już jej pobieżny przegląd przekonuje o wielości i różnorodności podejmowanych inicjatyw: od propozycji z astronomii (np. Galaxy Zoo), medycyny (np. AED4), prawa (np. LawPivot), biznesu (np. Cisco), informatyki (np. ComCrowd), przez e-handel (np. Wishabi), gastronomię (np. Bar Database) i reklamę (np. Zooppa), po typowe serwisy Web 2.0 (Wikipedia, Facebook). Wśród wymienionych projektów nie brakuje inicjatyw realizujących różnorodne formy crowdsourcingu, np. Lanzanos (crowdfunding), Local By Us (crowdvoting), Innovation Exchange (collective intelligence), Mindpixel (crowdcreation), jak i angażujących różne kategorie użytkowników sieci, w tym m.in. właścicieli firm i przedsiębiorstw (np. Squadhelp), naukowców (np. InnoCentive), programistów (np. Starbytes), konsumentów (np. HuMuch), projektantów (np. Choosa), kibiców (np. Tribevine), studentów (np. Students of Fortune), użytkowników sieci komórkowych (np. Mob4Hire), osób poszukujących zaginionych członków rodziny (np. Katrina PeopleFinder Project) itp. Mimo że w zdecydowanej mniejszości, w wykazie „Wikipedii” zaznaczają swoją obecność także projekty inicjowane przez instytucje non profit, w tym: biblioteki (np. Civil War Diaries \& Letters Transcription Project), muzea (np. FromThePage) i archiwa (np. Citizen Archivist Dashboard).

${ }^{4}$ D. C. Brabham, dz. cyt.

15 List of crowdsourcing projects. W: Wikipedia, the free encyclopedia [on-line] [dostęp 30 listopada 2012]. Dostępny w World Wide Web: http://en.wikipedia.org/wiki/List_of_ crowdsourcing_projects. 


\section{Crowdsourcing w bibliotekarstwie}

Biblioteki wydają się naturalnie predestynowane do wykorzystania crowdsourcingu. Ograniczone i skromne budżety, jak i niewielka liczba pracowników są częstą przeszkodą w uruchamianiu projektów, zwłaszcza tych związanych z digitalizacją. Z drugiej strony, instytucje te cieszą się dużym zaufaniem i poparciem społecznym, a co za tym idzie - mają doświadczenie w angażowaniu wolontariuszy.

Temat crowdsourcingu w bibliotekarstwie stanowi swoiste novum. O ile jeszcze jego znamion można doszukiwać się w różnego typu akcjach społecznych i promocyjnych realizowanych przez biblioteki w sposób tradycyjny (konkursy, spotkania z czytelnikami, zbiórki i adopcje książek), to projekty zaawansowane, a więc angażujące społeczność internetową do rozwiązywania konkretnych problemów pojawiających się w bibliotekach lub wykorzystujące pomysły przez nią generowane na szerszą skalę, znajdują się dopiero $w$ fazie rozwoju.

Prekursorami w inicjowaniu bibliotecznych projektów crowdsourcingowych są biblioteki australijskie. W latach 2006-2008 Narodowa Biblioteka Australii (ang. National Library of Australia) uruchomiła dwa prowadzane na szeroką skalę przedsięwzięcia: „Picture Australia” i „Australian Historic Newspapers". W pierwszym użytkownicy sieci zostali zaproszeni do przesyłania zdjęć tematycznie dotyczących Australii. Początkowo można było je przesyłać na platformę Flickr, gdzie na potrzeby gromadzenia zasobu stworzono dwie kategorie tematyczne: „Australia Day” oraz „People, Places and Events”. Następnie metadane i miniatury obiektów co tydzień były przenoszone do odrębnej kolekcji, w której gromadzono już zdjęcia pochodzące z ponad 50 instytucji zajmujących się ochroną dziedzictwa kulturowego zarówno w Australii, jak i za granicą (www.pictureaustralia.org). W czerwcu 2008 r. cały zasób, liczący ponad 55 tys. obiektów, przeniesiono do serwisu Trove ${ }^{16}$. Obecnie (2012 r.) użytkownicy nadal mogą dodawać zdjęcia przez platformę Flickr, w ramach której - dla odróżnienia od projektu zasadniczego - wydzielono specjalną grupę „Trove: Australia in Pictures” ${ }^{17}$.

${ }_{16}$ R. Holley, dz. cyt.

17 F. Hooton, PictureAustralia and the flickr Effect. „Gateways” [on-line] April 2006, no. 80 [dostęp 30 listopada 2012]. Dostępny w World Wide Web: http://pandora.nla.gov. au/pan/11779/20060524-0000/www.nla.gov.au/pub/gateways/issues/80/story01. html; Australian pictures in Trove [on-line]. Trove [dostęp 30 listopada 2012]. Dostępny w World Wide Web: http://trove.nla.gov.au/general/australian-pictures-in-trove. 
Drugi z projektów australijskich polega na dokonywaniu przez użytkowników identyfikacji i korekty tekstów starych gazet (pochodzących z lat 1803-1954) zeskanowanych techniką rozpoznawania pisma (ang. Optical Character Recognition, dalej: OCR). Projekt został uruchomiony w 2008 r., a już dwa lata później liczył ponad 12 mln linijek tekstu poprawionych przez tysiące użytkowników ${ }^{18}$. Statystyki publikowane na stronach projektu dowodzą jego niesłabnącej popularności: miesięcznie odnotowuje się około 800 różnego typu prac podjętych przez użytkowników ${ }^{19}$. Liczba $\mathrm{w}$ pełni przeszukiwalnych artykułów, udostępnianych, podobnie jak w poprzednim projekcie, również z poziomu serwisu Trove, w listopadzie 2012 r. przekroczyła $141 \mathrm{mln}^{20}$.

Podobne projekty z sukcesem realizują także książnice w Stanach Zjednoczonych. W styczniu 2008 r. twórcy serwisu Flickr wraz z Biblioteką Kongresu (ang. The Library of Congress) stworzyli projekt „Flickr: The Commons”, udostępniając w serwisie fotograficznym Flickr zdjęcia ze swoich zbiorów i pozwalając użytkownikom na identyfikację miejsc, osób i sytuacji prezentowanych na zdjęciach.

$\mathrm{W}$ cykl tego typu inicjatyw wpisuje się również kolejny projekt Biblioteki Kongresu - „Civil War Faces”, służący identyfikacji kolekcji 886 zdjęć żołnierzy i ich rodzin z okresu wojny secesyjnej, a uruchomiony w marcu 2012 r. Korzystając z serwisu Flickr, użytkownicy próbują zidentyfikować widniejące na fotografiach osoby. Jak dowodzą dane zamieszczone na stronie projektu (140 tys. wyświetleń), w wielu przypadkach takie próby okazują się udane ${ }^{21}$.

18 Por. R. Holley, Many Hands Make Light Work: Public Collaborative OCR Text Correction in Australian Historic Newspapers, [Canberra] 2009, dostępny także w Internecie: http://eprints.rclis.org/bitstream/10760/12907/1/ANDP_Many_Hands.pdf; taż, How Good Can It Get? Analysing and Improving OCR Accuracy in Large Scale Historic Newspaper Digitisation Programs. „D-Lib Magazine” [on-line] 2009, vol. 15, no. 3/4 [dostęp 30 listopada 2012]. Dostępny World Wide Web: http://www.dlib.org/dlib/march09/ holley/03holley.html.

19 Przykładowo jednego dnia (2 sierpnia 2012 r.) odnotowano ponad 98 tys. korekt (linijek i stronic) tekstów gazet. Por. Contribute [on-line]. Trove [dostęp 30 listopada 2012]. Dostępny w World Wide Web: http://trove.nla.gov.au/.

${ }^{20}$ Australian Newspaper Digitisation Program [on-line]. National Library of Australia [dostęp 30 listopada 2012]. Dostępny w World Wide Web: http://www.nla.gov.au/ndp/.

${ }_{21}$ Civil War Faces [on-line]. Flickr [dostęp 30 listopada 2012]. Dostępny w World Wide Web: http://www.flickr.com/photos/library_of_congress/sets/72157625520211184/. 


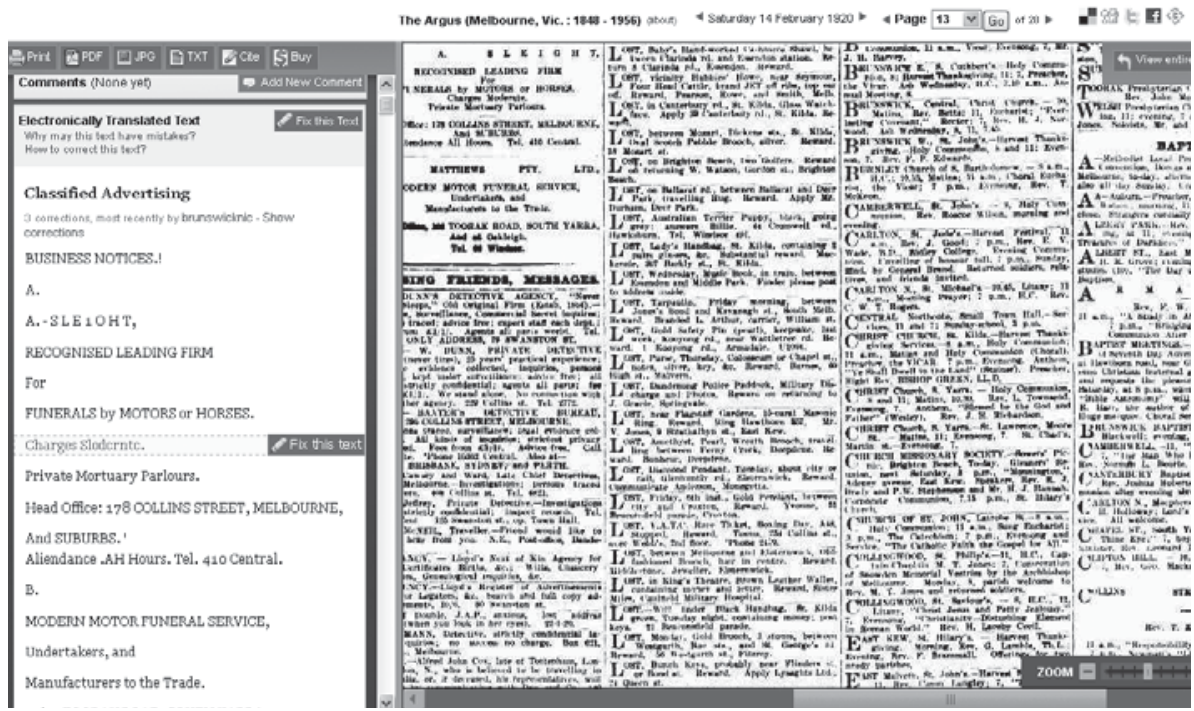

Rysunek 1a. Australian Historic Newspapers - przykład tekstu przed korektą

Źródło: Classified Advertising, „The Argus” (Melbourne, Vic.: 1848-1956), Saturday 14 February 1920, page 13 [on-line]. Trove [dostęp 30 listopada 2012]. Dostępny w World Wide Web: http://trove.nla.gov.au/ndp/del/article/1677398.

\begin{tabular}{|c|c|c|c|}
\hline $\begin{array}{l}\text { Classified Advertising } \\
\text { The Argus Malboume, Wo. } \\
\text { Advertising }\end{array}$ & : 1848 - 1956) Saturday 14 Februar & 1920, page 13 & \\
\hline Changed & By & Old Lines & New Lines \\
\hline 2012-08-25 01:44:11.0 & user:public:brunswicknic & $\begin{array}{l}\text { BRUNSWICK BAPTIST.Mboming. Rev." "' E. } \\
\text { Blackwell; evening, Rev. 11. It. Stewart. }\end{array}$ & $\begin{array}{l}\text { BRUNSWICK BAPTIST.Mbming. Rev. A E. } \\
\text { Blackwell; evening. Rev. H. R. Stewart. }\end{array}$ \\
\hline 2012-02-05 20:25:41.0 & user:public:kjharris & 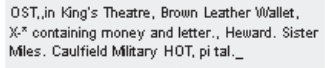 & $\begin{array}{l}\text { LOST, in King's Theatre, Brown Leather Wallet, } \\
\text { containing money and letter, Reward. Sister } \\
\text { Males. Caulfield Military Hospital. }\end{array}$ \\
\hline 2011-02-28 18:13:40.0 & user:public:navaretti & 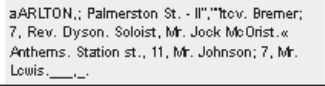 & $\begin{array}{l}\text { CARLTON, Palmerston St. - 11[am?] Rev. Bremer; } \\
7 \text { [pm?], Rev. Dyson. Soloist, Mt. Jock Mb Orist. } \\
\text { Anthems. Station st., } 11 \text { [am?], Mr. Johnson; } 7 \text { [pm?], Mr. } \\
\text { Lewis. }\end{array}$ \\
\hline
\end{tabular}

Rysunek 1b. Australian Historic Newspapers - fragmenty tekstu z rys. 1a po korekcie użytkowników

Źródło: „The Argus” (Melbourne, Vic.: 1848-1956), Saturday 14 February 1920, page 13 [on-line]. Trove [dostęp 30 listopada 2012]. Dostępny w World Wide Web: http://trove.nla.gov.au/ndp/del/correction/1677398. 


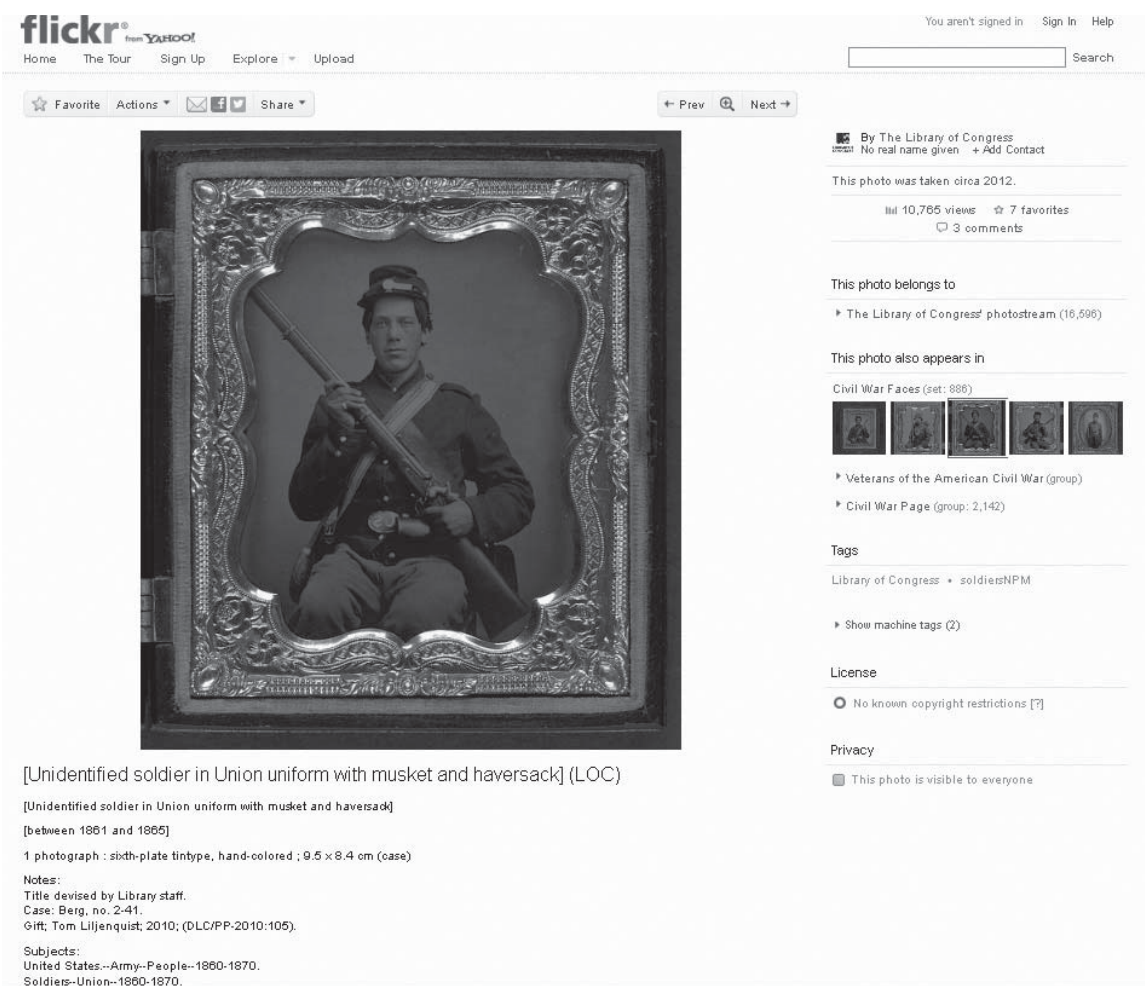

Rysunek 2. Civil War Faces - przykład niezidentyfikowanej fotografii

Źródło: [Unidentified soldier in Union uniform with musket and haversack] (LOC) [on-line]. Flickr: Library of Congress' photostream [dostęp 30 listopada 2012]. Dostępny w World Wide Web: http://www.flickr.com/photos/library_of_congress/5228555073/.

Od kwietnia 2011 r. także Nowojorska Biblioteka Publiczna (ang. New York Public Library) korzysta z pomocy internautów, realizując projekt „What's on the menu”. Początkowo jego celem miało być odczytanie kolekcji 9 tys. zeskanowanych z OCR historycznych menu nowojorskich restauracji, zanim trafią one do bibliotecznej galerii cyfrowej. Zeskanowane z OCR strony menu udostępniono na stronie WWW, a następnie poproszono użytkowników o przepisywanie tekstów dań. Ponieważ zadanie wykonano w ciągu trzech miesięcy, digitalizacji poddano kolejne dokumenty. Na koniec listopada 2012 r. transkrypcją objęto ponad milion opisów dań z 15630 menu zarejestrowanych w projekcie ${ }^{22}$.

${ }^{22}$ What's on the menu [on-line]. New York Public Library [dostęp 30 listopada 2012]. Dostępny w World Wide Web: http://menus.nypl.org/. 

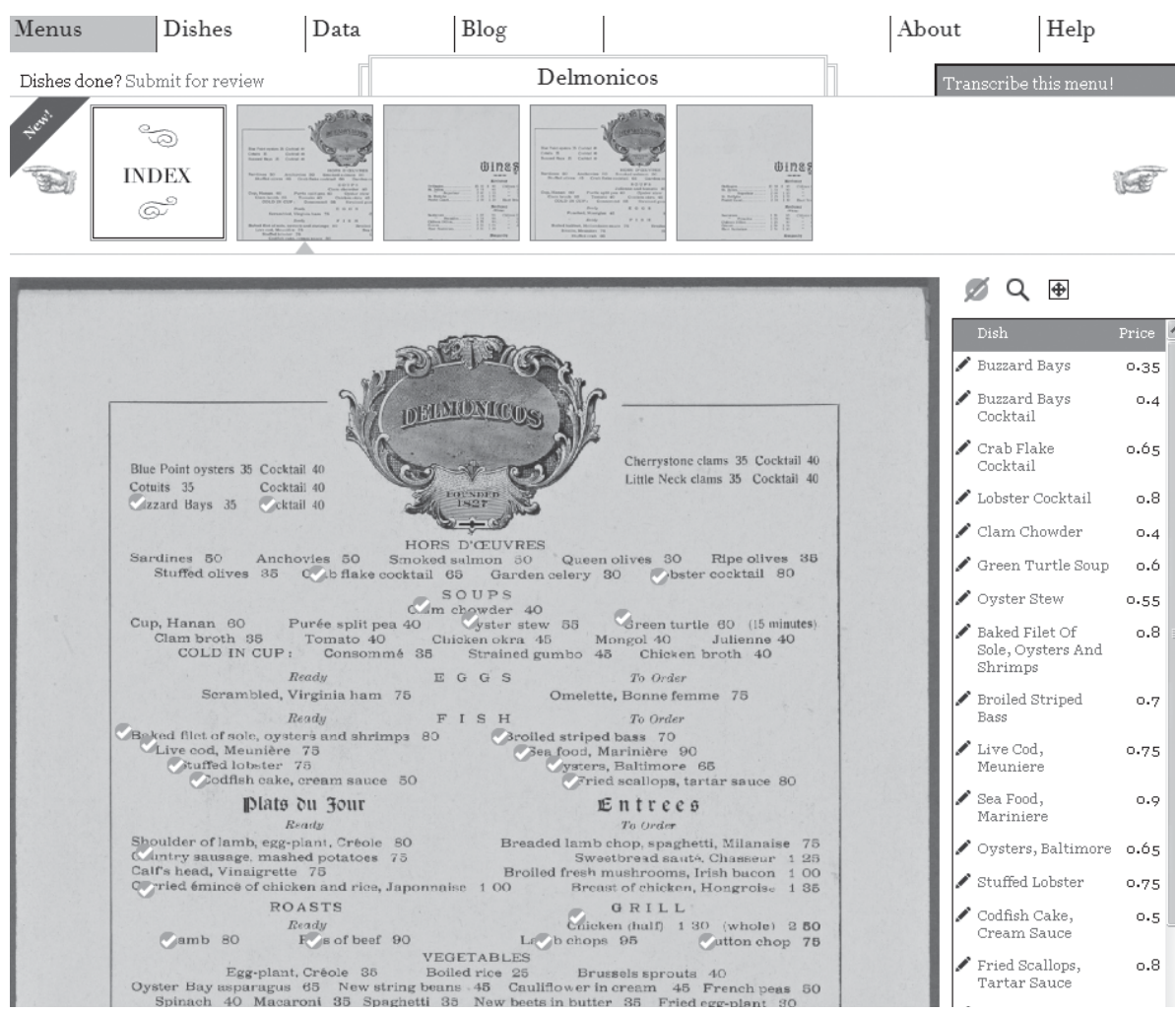

Rysunek 3. What's on the menu - interfejs umożliwiający korektę tekstu

Źródło: Delmonicos [on-line]. What's on the menu. New York Public Library [dostęp 30 listopada 2012]. Dostępny w World Wide Web: http://menus.nypl. org/menu_pages/68181.

Jeśli chodzi o biblioteki polskie, to crowdsourcing jest dla nich zjawiskiem nowym (pomijając obecność profili bibliotek w serwisach społecznościowych i wykorzystywanie na ich stronach domowych mechanizmów Web 2.0, co przez niektórych badaczy nie jest uznawane za przejaw crowdsourcingu), a ze względu na istniejące przepisy prawne (choćby „Ustawę o zbiórkach publicznych” czy „Ustawę o prawie autorskim”) i bariery technologiczne (wciąż ograniczony dostęp do szerokopasmowego Internetu i szybkość jego łączy) - kłopotliwym.

Gdyby za crowdsourcing uznać każde otwarte zaproszenie skierowane za pośrednictwem Internetu do użytkowników danej biblioteki, to przykładem sięgania do mądrości tłumu mógłby być np. konkurs na na- 
zwę Oddziału dla Dzieci Wojewódzkiej Biblioteki Publicznej w Krakowie ${ }^{23}$ czy pomysły jarocińskiej Biblioteki „Pod Ratuszem” i Miejskiej Biblioteki Publicznej w Piekarach Śląskich zachęcające czytelników do nadsyłania pocztówek z wakacji, mających następnie służyć jako eksponaty w organizowanych w obu bibliotekach wystawach ${ }^{24}$.

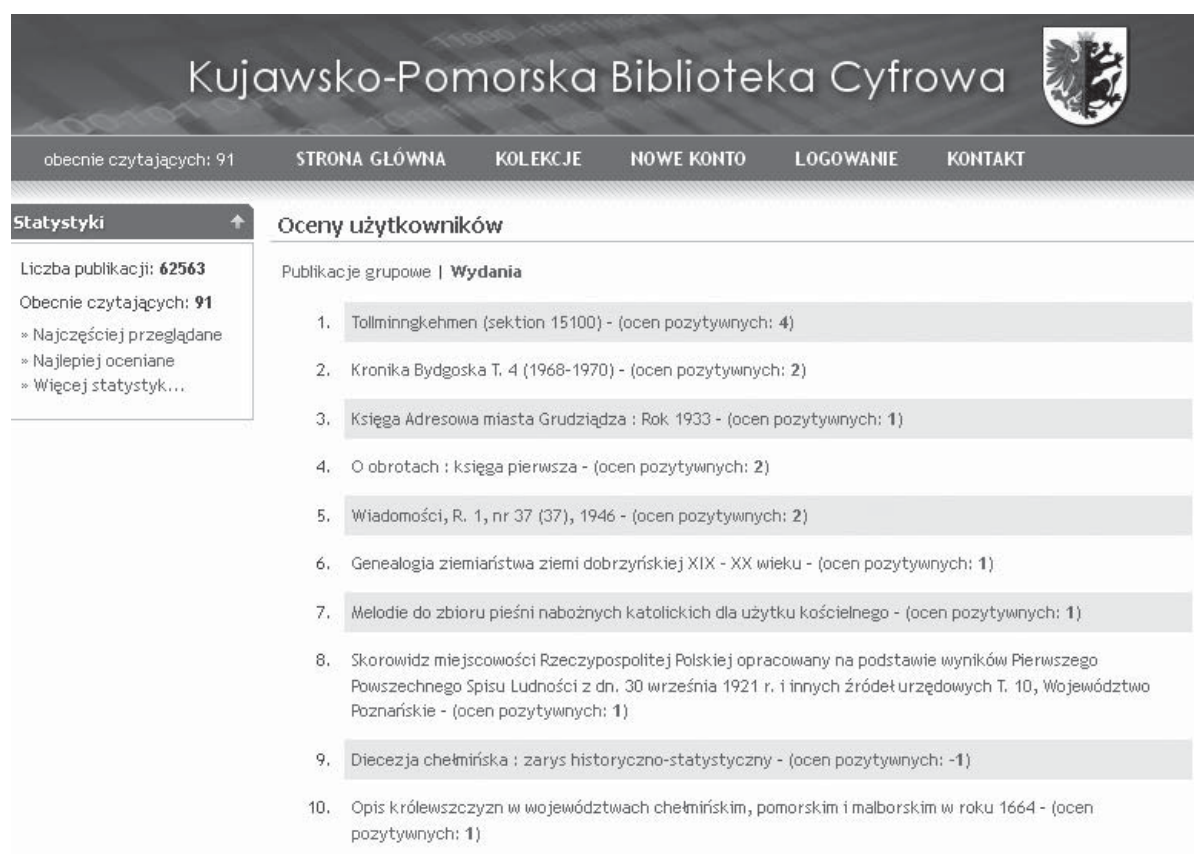

Rysunek 4. Kujawsko-Pomorska Biblioteka Cyfrowa - publikacje najlepiej oceniane

Źródło: Kujawsko-Pomorska Biblioteka Cyfrowa [on-line] [dostęp 30 listopada 2012]. Dostępny w World Wide Web: http://kpbc.umk.pl/dlibra/pubvotes.

${ }^{23}$ Regulamin konkursu na nazwę Oddziału dla Dzieci Wojewódzkiej Biblioteki Publicznej w Krakowie [on-line]. Wojewódzka Biblioteka Publiczna w Krakowie [dostęp 30 listopada 2012]. Dostępny w World Wide Web: http://www.rajska.info/do-pobrania/funcstartdown/389/.

${ }^{24}$ Biblioteka czeka na pocztówki. „Gazeta Jarocińska” [on-line] z dn. 12 lipca 2012 r. [dostęp 30 listopada 2012]. Dostępny w World Wide Web: http://www.jarocinska.pl/index.php?option=com_content\&view=article\&id=4360\%3Abiblioteka-czeka-na-pocztowki\&catid=12\%3Aprzeczytaj\&Itemid=13; W rodzinie najlepiej [on-line]. Miejska Biblioteka Publiczna w Piekarach Śląskich [dostęp 30 listopada 2012]. Dostępny w World Wide Web: http://www.biblioteka.piekary.pl/news.php?nid=1402. 
Gdyby jednak przyjąć - jak chce większość badaczy - że crowdsourcing to działalność polegająca na wykonywaniu określonych zadań przez użytkowników sieci, wówczas jego mechanizmów można by dopatrzyć się $\mathrm{w}$ funkcjach oprogramowania dLibra, rozwijanego na potrzeby polskich bibliotek cyfrowych. Wraz z premierą wersji 4.0 tego systemu w styczniu 2008 r. użytkownikom umożliwiono tworzenie i udostępnianie listy ulubionych publikacji, ich ocenianie (oceną + lub -) oraz opatrywanie słowami kluczowymi (prywatnymi i publicznymi). Mimo że w wersji 5.0 (2010 r.) funkcje społecznościowe zostały jeszcze bardziej wyeksponowane, badania stopnia ich wykorzystania, opisane przez Marcina Werlę na podstawie danych nadesłanych przez operatorów 10 największych bibliotek cyfrowych, dowiodły ich nikłego zastosowania ${ }^{25}$.

\section{Podsumowanie}

Pierwsze doświadczenia bibliotek na świecie dowodzą, że crowdsourcing jest koncepcją obiecującą. Biblioteki wdrażają go przede wszystkim w zakresie informowania społeczności o podejmowanych inicjatywach, w tym istniejących obiektach cyfrowych, jak i wzbogacania oraz korekty posiadanych danych. 0 ile bibliotekom zagranicznym nie jest obce ani korzystanie ze zbiorowej mądrości użytkowników bibliotek (np. powołanie Bibliotecznej Rady Młodych w Upper Dublin Public Library), ani społeczne pozyskiwanie funduszy (np. adopcja książki w Państwowej Bibliotece Bawarii w Monachium) czy też współtworzenie zasobów treściowych z czytelnikami (np. KanWiki w Kankakee Public Library), o tyle niestety polskie biblioteki na razie nie mają czym pochwalić się na tym polu.

Jak wskazuje Rose Holley - menedżer projektu „Australian Historic Newspapers" - warto jednak przekonać się do stosowania crowdsourcingu w bibliotekach, niesie on bowiem ze sobą wiele pozytywnych implikacji. Dzięki niemu biblioteki mogą:

- osiągać własne cele szybciej, niż gdyby działały w pojedynkę;

- osiągać własne cele nawet wówczas, gdy nie będą dysponowały odpowiednim zapleczem finansowym i kadrowym;

${ }_{25}$ M. Werla, Web 2.0 i (polskie) biblioteki cyfrowe. „Biuletyn EBIB” [on-line] 2012, nr 2 (129) [dostęp 30 listopada 2012]. Dostępny w World Wide Web: http://www.nowyebib. info/images/stories/numery/129/129_werla_pdf. 
- budować nowe wirtualne społeczności i grupy użytkowników skupione wokół biblioteki;

- aktywizować użytkowników i zwiększać stopień wykorzystywania zbiorów;

- lepiej wykorzystywać wiedzę, umiejętności i zainteresowania użytkowników;

- identyfikować dane (np. przez opisywanie obiektów);

- poprawiać jakość danych (np. przez korektę opisów bibliograficznych w katalogach czy zasobach cyfrowych) i zwiększać relewantność wyszukiwania;

- zwiększać wartość przechowywanych danych (np. przez oznaczanie publikacji słowami kluczowymi, przygotowywanie recenzji);

- lepiej dostosowywać ofertę usługową do potrzeb użytkowników;

- podnieść prestiż własnej placówki i jej znaczenie społeczne;

- budować zaufanie i lojalność użytkowników wobec biblioteki;

- wykształcać poczucie wspólnoty publicznej i odpowiedzialności za dziedzictwo kulturowe ${ }^{26}$.

Zdaniem Michaela Stephensa - specjalisty od zastosowań nowoczesnych technologii w bibliotekarstwie i wykładowcy akademickiego na Uniwersytecie w San Jose (ang. San Jose State University) - crowdsourcingu w bibliotekach nie da się uniknąć. Mimo że „będzie [on] kolejnym kamieniem milowym w długim łańcuchu zakłóceń działalności bibliotek, jakich są one świadkami od narodzin systemu WWW [...] i doprowadzi do podziału bibliotek na te, które będą pracować ze społecznościami, i te, które powierzą zadania w ich ręce, to [jego] zastosowanie doprowadzi biblioteki do [urzeczywistnienia modelu - przyp. M. K.] Biblioteki 2.0, a następnie jeszcze dalej"27.

${ }^{26}$ R. Holley, Crowdsourcing: How and Why...

27 „Crowdsourcing in libraries will be another milestone in the long chain of disruptions the library has witnessed since the birth of the World Wide Web. Although social networking and technological literacy have improved the library's capacity for social engagement, the continuing maturity of said social networks, along with increased activity and risk-taking in crowdsourcing activities, will separate the libraries who are trying to work with their communities from the libraries that are throwing work at the community. Harnessing the power of crowdsourcing will bring the library into Library 2.0 and then, much further". Za: M. Stephens, Crowdsourcing and Library 2.0 [on-line]. Crowdsourcing and Crowdfunding - The Industry Website [dostęp 30 listopada 2012]. Dostępny w World Wide Web: http://www.crowdsourcing.org/document/crowdsourcing-andlibrary-20/14785. 


\section{The application of crowdsourcing conception in libraries}

ABstract: Crowdsourcing means the separation of one organization area and putting it into the hands of the crowd - an organized community in the form of an open call. This community can be created from both high class professionals and amateurs. Currently, crowdsourcing is implemented primarily in companies and NGOs. Since the implementation of solutions based on crowdsourcing is quite straight forward, it is also made use of in civic and social activities, including ventures initiated by archives, museums and libraries. This article brings the idea of crowdsourcing and examples of its mechanisms in libraries.

KEYWORDS: collective intelligence, crowdsourcing, libraries, windsom of the crowd 